Tropical Journal of Pharmaceutical Research February 2020; 19 (2): 239-246

ISSN: $1596-5996$ (print); 1596-9827 (electronic)

(C) Pharmacotherapy Group, Faculty of Pharmacy, University of Benin, Benin City, 300001 Nigeria.

\title{
Chlorobenzoxime inhibits respiratory syncytial virus infection in neonatal rats via up-regulation of IFN-y in dendritic cells
}

\author{
Junzhao $\mathrm{Li}^{1}$, Yonghai Zhang ${ }^{2 \star}$, Hongmei Qiao ${ }^{3}$, Yingji Jin ${ }^{1}$, Jianmin Wang ${ }^{1}$, \\ Binghua $\mathrm{Yao}^{1}$ \\ ${ }^{1}$ Department of Pediatrics, ${ }^{2}$ Department of Neurosurgery, Jiangsu Taizhou People's Hospital, Taizhou, Jiangsu 225300, \\ ${ }^{3}$ Department of Pediatrics, The First Affiliated hospital of Jilin University, Changchun, Jilin 130061, China
}

*For correspondence: Email: AndresHillnty@yahoo.com; Tel: 0086-0523-89890319

Revised accepted: 21 January 2020

\begin{abstract}
Purpose: To investigate the effect of chlorobenzoxime on respiratory syncytial virus (RSV) infection in vitro in lung alveolar cells and in vivo in neonatal rats, as well as the mechanism of action involved. Methods: RSV infection in neonatal rats was induced via intranasal administration of 2 × 106PFU viral particles. Reverse transcriptase-polymerase chain reaction (RT-PCR) and western blotting were used for determination of changes in interleukin expression.

Results: RSV infection in BEAS-2B cells caused significant reduction in viability and marked alteration in morphological appearance $(p<0.05)$. Exposure of RSV-infected BEAS-2B cells to chlorobenzoxime prevented viability reduction and changes in morphology, and led to reductions in RSV-mediated increases in levels of interleukin-6 and interleukin-8. Moreover, RSV infection significantly enhanced ROS levels in BEAS-2B cells, when compared to control cells $(p<0.05)$. Chlorobenzoxime at a concentration of $30 \mu \mathrm{M}$ completely suppressed RSV-mediated generation of ROS in BEAS-2B cells. In neonatal rats, RSV-induced upregulation of interleukin-4, interleukin-13 and TNF-a, were suppressed in bronchoalveolar lavage fluid (BALF) and lung tissues by chlorobenzoxime. Moreover, the RSVmediated reduction in IFN-y was maximally blocked by chlorobenzoxime at a dose of $10 \mathrm{mg} / \mathrm{mL}$. Chlorobenzoxime enhanced the proportion of IFN- $y$-producing cells in neonatal rat BALF.

Conclusion: Chlorobenzoxime exhibits antiviral against RSV infection in neonatal rats via increase in dendritic cell population, leading to inhibition of cytokine production. Therefore, chlorobenzoxime is a potential therapeutic agent for RSV infection.
\end{abstract}

Keywords: Respiratory syncytial virus, Cytokines, Dendritic cells, Lung aveolar cells, Morphology, Interleukins

This is an Open Access article that uses a fund-ing model which does not charge readers or their institutions for access and distributed under the terms of the Creative Commons Attribution License (http://creativecommons.org/licenses/by/4.0) and the Budapest Open Access Initiative (http://www.budapestopenaccessinitiative.org/read), which permit unrestricted use, distribution, and reproduction in any medium, provided the original work is properly credited.

Tropical Journal of Pharmaceutical Research is indexed by Science Citation Index (SciSearch), Scopus, International Pharmaceutical Abstract, Chemical Abstracts, Embase, Index Copernicus, EBSCO, African Index Medicus, JournalSeek, Journal Citation Reports/Science Edition, Directory of Open Access Journals (DOAJ), African Journal Online, Bioline International, Open-J-Gate and Pharmacy Abstracts

\section{INTRODUCTION}

Respiratory tract disorders are mostly caused by infections due to rhinovirus, coronavirus, para- influenza virus and adenovirus [1]. These infections generally affect the nostrils, pharynx, larynx and sinuses. The associated symptoms are sinusitis, common cold, laryngitis and 
pharyngitis [2]. Respiratory syncytial virus (RSV) belongs to the family of Paramyxoviridae. Its non-segmented body consists of negativestranded RNA as genetic material. Most cases of respiratory diseases in children and elderly people are due to RSV infection [3,4]. Studies have revealed that RSV infection in mice damages lung epithelial cells through generation of reactive oxygen species (ROS) $[5,6]$.

It has been shown that the pathogenesis of chronic obstructive lung disorder is associated with the induction of oxidative stress in pulmonary cells [7]. Infection due to RSV causes generation of ROS and increases production of interleukin-8 and interleukin-6 in BALF and lung tissues of mice [8]. Higher level of the inflammatory cytokine generation by RSV infection is associated with disturbance in equilibrium between cytokine types 1 and 2 . A disturbance in this equilibrium by increase in type 2 or by decrease in type 1 plays an important role in RSV-induced pathogenesis of bronchiolitis [9]. It has been shown that RSV infection either directly damages pulmonary epithelial cells, or induces inflammation of lung airways in infants and immune-compromised patients. Inflammation of lung airways leads to secretion of pro-inflammation mediators and recruitment of inflammatory cells, and increased mucus production [10]. Suppression of lung airway inflammation by inhibition of viral replication is considered the most important strategy for the treatment of RSV infection [10].

Inflammatory disorders in humans have been treated over the years using various therapeutic agents [11,12]. Phytochemical and clinical studies have revealed that anti-inflammatory compounds contain functional groups similar to those in chlorobenzoxime, which are associated with modulation of immune system in the hosts $[11,12]$. Compounds with anti-oxidant properties protect damage to endothelial cells by neutralization of pro-oxidant radicals and modulation of antioxidant defence systems [1315]. The present study investigated the effect of chlorobenzoxime on respiratory syncytial virus (RSV) infection in vitro in lung alveolar cells, and in vivo in neonatal rats, and the mechanism involved.

\section{EXPERIMENTAL}

\section{Cell line and culture}

The BEAS-2B bronchial epithelial cell line was obtained from the American Type Culture Collection (ATCC; Rockville, MD, USA). The cells were cultured in DMEM (GibcoGrand
Island, NY, USA) containing $10 \%$ fetal bovine serum (FBS) and $2 \mathrm{mM} \mathrm{L-glutamine.} \mathrm{In} \mathrm{addition,}$ the medium contained $100 \mathrm{U} / \mathrm{mL}$ penicillin, and $100 \mathrm{mg} / \mathrm{mL}$ streptomycin (Life Technologies, Grand Island, NY, USA). The cells were seeded at a density of $3 \times 10^{6}$ cells per well in accordance with the experimental design and grown for $36 \mathrm{~h}$ before the start of the experiment. For the in vitro study, respiratory syncytial virus was added to the BEAS-2B cells at various doses. Chlorobenzoxime was added to the monolayer of BEAS-2B cells at the indicated concentrations to determine its effect on cell viability.

\section{Virus and reagents}

Human plaque-purified RSV-A2 (ATCC) viral strain was grown in HEp-2 cells (ATCC).

\section{Determination of effect of chlorobenzoxime on cell viability}

The effect of chlorobenzoxime on viability of the RSV infected or non-infected BEAS-2B cells was determined using 3-(4,5-dimethylthiazol-2yl)-2,5-diphenyltetrazolium bromide (MTT) assay. In this assay, $200 \mu \mathrm{L}$ of the cell suspension containing $2 \times 10^{6}$ cells per $\mathrm{ml}$ was seeded in 96-well culture cell plates. The cells were incubated for $24 \mathrm{~h}$ with chlorobenzoxime at the indicated concentrations, followed by addition of $20 \mu \mathrm{L}$ of MTT solution ( $5 \mathrm{mg} / \mathrm{mL}$ ) to each well. The plates were subjected to incubation for $4 \mathrm{~h}$ at $37^{\circ} \mathrm{C}$. Thereafter, the plates were rinsed thrice using PBS, and DMSO (150 $\mu \mathrm{L}$ ) was added to each of the wells, followed by shaking on a shaker for 10 min to solubilize the formazan crystals formed. Then, absorbance was read at $450 \mathrm{~nm}$ in a Bio-Rad iMark plate reader.

\section{Western blot analysis}

After chlorobenzoxime treatment for $24 \mathrm{~h}$, BEAS-2B cells were harvested and washed two times with PBS, and then treated with RIPA lysis buffer mixed with $1 \%$ phenylmethylsulfonyl fluoride. The cell lysate was subjected to centrifugation at $12,000 \mathrm{~g}$ for $25 \mathrm{~min}$ at $4{ }^{\circ} \mathrm{C}$ for the separation of insoluble cellular components. Protein concentration was determined with bicinchoninic acid assay using commercially available BCA kit (Pierce Chemical Co., Rockford, IL, USA) in the lysates. The protein was subjected to SDS-polyacrylamide gel electrophoresis and subsequently transferred onto nitrocellulose membrane (Millipore Corp., Billerica, MA, USA). The membrane was incubated with non-fat milk powder mixed with 
$0.05 \%$ Tween-20 at room temperature for 90 min, to block non-specific binding. Thereafter, the membrane was incubated with primary antibodies overnight at $4{ }^{\circ} \mathrm{C}$, followed by washing and $1 \mathrm{~h}$ incubation with secondary antibody. Band visualization was carried out using enhanced chemiluminescence.

\section{Reverse transcriptase-polymerase chain reaction (RT-PCR)}

Total RNA was extracted from BEAS-2B cells infected with RSV and non-infected cells (both treated with chlorobenzoxime) for $24 \mathrm{~h}$, using RNeasy mini kit (Qiagen) in accordance with the manual protocol. Then, $1 \mu \mathrm{g}$ RNA from each sample was reverse-transcribed to cDNA using oligo(dT) primers and SuperScript III RT (Invitrogen). The following conditions were used for the determination of gene expression using touchdown PCR analysis: one cycle for $5 \mathrm{~min}$ at $92{ }^{\circ} \mathrm{C}, 12$ cycles of $30 \mathrm{~s}$ at $92{ }^{\circ} \mathrm{C}$ for $30 \mathrm{sec}$ at 65 ${ }^{\circ} \mathrm{C}$, and for $30 \mathrm{sec}$ at $70^{\circ} \mathrm{C}$; 25 cycles for $30 \mathrm{~s}$ at $95^{\circ} \mathrm{C}$, for $30 \mathrm{~s}$ at $52{ }^{\circ} \mathrm{C}$ and for $30 \mathrm{~s}$ at $70{ }^{\circ} \mathrm{C}$; and one cycle for $10 \mathrm{~min}$ at $70{ }^{\circ} \mathrm{C}$. The following oligonucleotide primers were used for the determination of mRNA levels corresponding to interleukin-6, interleukin -8 and 18S rRNA. The products of RT-PCR were subjected to visualization using $2 \%$ agarose gels stained with ethidium bromide, with 18S rRNA as the loading internal control. Rotor-Gene 6000 RealTime PCR machine (Corbett Research, Sydney, Australia) combined with SYBR Premix Ex Taq (Thermo) was used to run the RT-qPCR.

\section{Measurement of ROS production}

The levels of ROS generation in RSV-infected and non-infected BEAS-2B cells were determined using the H2DCFDA fluorescent probe. Microplate spectrofluorometer (Molecular Devices Corp., Sunnyvale, CA, USA) was used for the measurement of fluorescence at absorption and emission wavelengths of 490 and $528 \mathrm{~nm}$, respectively. The RSV-infected and non-infected BEAS-2B cells treated with chlorobenzoxime for $24 \mathrm{~h}$ were subjected to incubation with H2DCFDA fluorescent probe at a concentration of $50 \mathrm{mM}$ at $37^{\circ} \mathrm{C}$ for $3 \mathrm{~h}$. The cell suspension was loaded onto the coverslips of 6-well plates for examination under fluorescence microscope (Nikon, Melville, NY, USA).

\section{Animals and treatment}

A total of 15 pregnant female Sprague-Dawley rats were supplied by the Guangdong Medical Laboratory Animal Centre, Guandong, China. The rats were acclimatized under laboratory environment with 12-h light/12-h dark cycle at laboratory temperature of $23 \pm 2{ }^{\circ} \mathrm{C}$ and relative humidity of $55-60 \%$. The rats were provided access to feed and water ad libitum, and were housed individually in cages. The neonatal rats were closely monitored from first day of birth [post-natal day 0 (P0)]. All pups were maintained carefully under standard laboratory environment, and provided free access to sterilized water.

Forty neonatal rats weighing approximately 15 $25 \mathrm{~g}$ were used for the present study. Thirty neonatal rats were infected with $2 \times 10^{6} \mathrm{PFU}$ RSV viral particles intranasally in the right nostril on post-natal day 5 , while 10 rats served as control group. The 30 neonatal rats were assigned to three groups of 10 rats each comprising 2treatment groups orally given chlorobenzoxime at doses 5 and $10 \mathrm{mg} / \mathrm{kg}$ doses on post-natal day 6 , and untreated, viralinfected group. Neonatal rats in normal control and untreated groups received normal saline alone. Approval for the study was obtained from the Animal Care and Ethical Committee of Huazhong Agriculture University (Wuhan, China; WAU/16/0026) and the animal experimental procedures were performed according to the guidelines of National Institutes of Health for Use of Laboratory Animals [16].

\section{Determination of inflammatory cytokines in lung tissues}

On post-natal day 9 , the neonatal rats were anesthetized using carbon dioxide inhalation, and sacrificed. The BALF and the pulmonary tissues were collected. Levels of inflammatory cytokines and anti-viral cytokines in the pulmonary tissues and BALF were measured using commercially available detection kits in accordance with the manufacturer's instructions. Lung tissue homogenates were prepared as outlined in a previous study [17]. A mechanical grinder was used for the preparation of lung tissue extract with $1.5 \mathrm{~mL}$ of PBS.

\begin{tabular}{lll}
\hline Gene & Forward & Reverse \\
\hline IL-6 & 5'-GACAGCCACTCACCTCTTCA-3' & 5'-CATCTTTGGAAGGTTCAGGTTGT-3' \\
IL-8 & 5'-CAGCCTTCCTGATTTCTGC-3' & 5'-ACTTCTCCACAACCCTCTGC-3' \\
18S rRNA & 5'-ATCCTGCCAGTAGCATATGC-3' & 5'-ACCCGGGTTGGTTTTGATCTG-3' \\
\hline
\end{tabular}


The lung homogenates were centrifuged for 15 min at $1,200 \mathrm{~g}$ to obtain the tissue supernatants. Immunoplaque assay was then used for the determination of viral titres in the lung tissue supernatants. The levels of interleukins- $4,-5$ and -13 , and TNF- $\alpha$ and IFN- $\gamma$ in the supernatants were determined using commercially available Ready-Set-Go detection kits (eBioscience) as per the manual procedures.

\section{Preparation of BALF and flow cytometric analysis}

On post-natal day 9 , the neonatal rats were anesthetized using carbon dioxide inhalation prior to collection of BALF. The procedure for BALF collection involved infusion of PBS through the tracheal tubes of neonatal rats into the lungs using a 25-gauge catheter $[18,19]$. The cells present in the BALF were collected and subsequently subjected to phorbol myristate acetate and ionomycin stimulation for $5 \mathrm{~h}$. Then, the cells were subjected to staining with antibodies against CD4, CD11b and CD11c (eBiosciences). The cells were also stained for intracellular IFN- $y$ (eBiosciences) in accordance with the instructions from the manufacturer. FlowJo software (Tree Star Inc, Ashland, OR, USA) was used for the calculation of cells present in the BALF.

\section{Statistical analysis}

Data are presented as mean \pm SD of results from three independent experiments. Statistical comparison among different groups was made using one-way ANOVA, followed by Student's $t$ test. Differences were taken as statistically significant at $p<0.05$.

\section{RESULTS}

Inhibition of RSV replication by chlorobenzoxime

The viability of BEAS-2B cells was decreased with increase in RSV infection multiplicities from 0.25 to $4.0 \mathrm{MOI}$ (Figure $1 \mathrm{~A}$ ). Exposure of noninfected BEAS-2B cells to chlorobenzoxime at concentrations of $5,10,15,20,25$ and $30 \mu \mathrm{M}$ did not have any effect on cell viability (Figure 1 B). Treatment of RSV-infected BEAS-2Bcells with chlorobenzoxime reversed the effect of RSV in a concentration-based manner. Chlorobenzoxime treatment of RSV-infected BEAS-2Bcells at a concentration of $30 \mu \mathrm{M}$ completely reversed the RSV-induced inhibitory effect on cell viability (Figure $1 \mathrm{C}$ ).

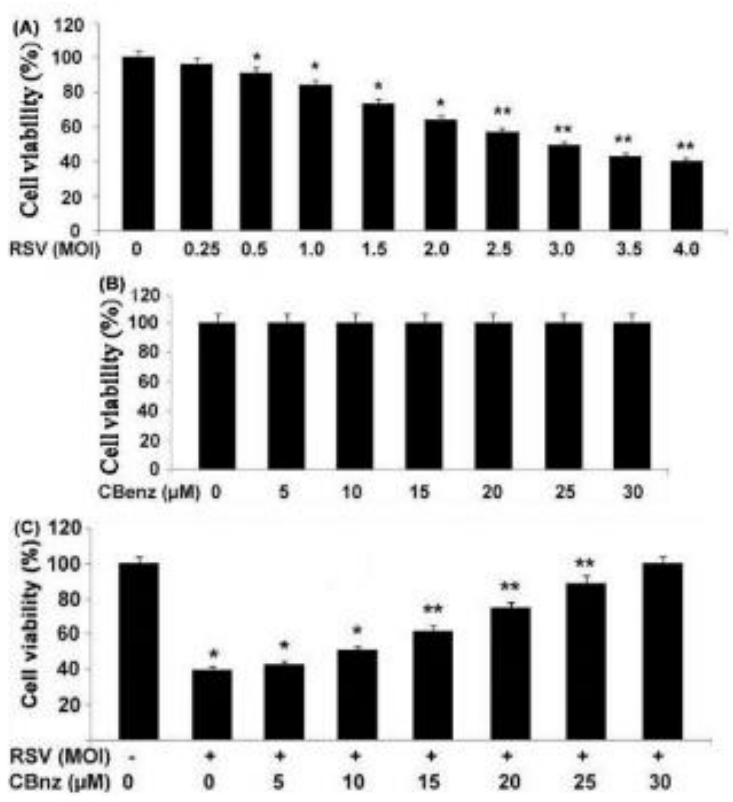

Figure 1: Effect of chlorobenzoximeon RSV-induced reduction of $B E A S-2 B$ cell viability. (A) Changes in BEAS-2Bcell viability on exposure to RSV at various infection multiplicities. (B)The cells were treated with various concentrations of chlorobenzoximefor $24 \mathrm{~h}$. (C) Cells infected with RSV were exposed to various concentrations of chlorobenzoxime. Data are presented as mean \pm SD $(n=3) ;{ }^{*} p<0.05,{ }^{* *} p<0.01$, compared with negative control cells

\section{Effect of chlorobenzoxime on RSV-induced changes in BEAS-2B cell morphology}

The RSV-infected BEAS-2B cells had prominent changes in morphological appearance such as detachment, rounding and necrosis. The cells were exposed to chlorobenzoxime at doses of 5 , $10,15,20,25$ and $30 \mu \mathrm{M}$, and then examined for morphological changes at $24 \mathrm{~h}$ post-infection (Figure 2). Treatment with chlorobenzoxime prevented RSV-induced changes in BEAS-2B cell morphology in a concentration-dependent manner. The effect of RSV infection on morphological changes inBEAS-2B cells was completely suppressed by chlorobenzoxime at a concentration of $30 \mu \mathrm{M}$.

\section{Chlorobenzoxime suppressed RSV-induced production of inflammatory cytokines in BEAS-2B cells}

In BEAS-2Bcells, RSV infection and subsequent treatment with chlorobenzoxime or normal saline (control) was followed with determination of expression levels ofinterleukin-6 and interleukin8. Western blot and RT-PCR showed that the expressions of interleukin- 6 and interleukin-8 in BEAS-2B cells were increased significantly by RSV-infection (Figure 3). However, treatment of the RSV-infected BEAS-2B cells with 
chlorobenzoxime led to marked and concentration-dependent reductions in expression levels of interleukin-6 and interleukin-8 level. The RSV-infected BEAS-2B cells were exposed to chlorobenzoxime at concentrations of $5,10,15,20,25$ and $30 \mu \mathrm{M}$, and inflammatory cytokine production was measured $24 \mathrm{~h}$ post-infection. The RSVmediated upregulations of interleukin- 6 and interleukin-8 were suppressed to minimum levels by chlorobenzoxime at a concentration of $30 \mu \mathrm{M}$.

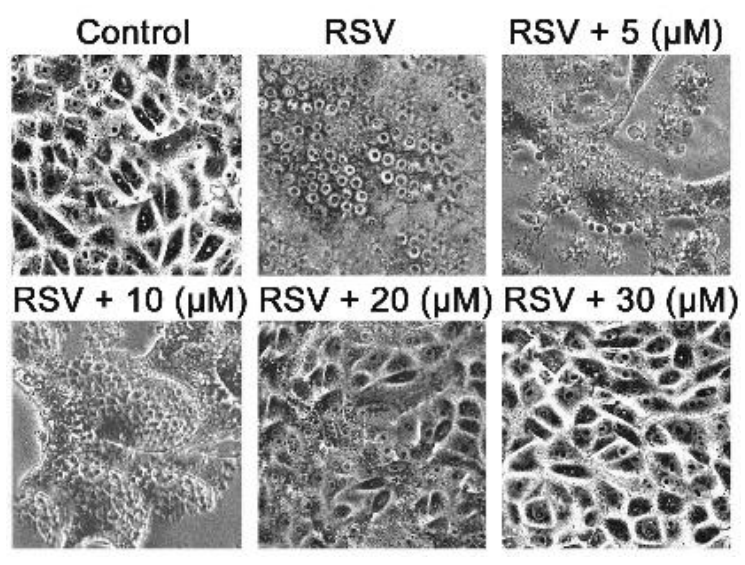

Figure 2: Effect of chlorobenzoxime on RSV-induced morphological changes in BEAS-2B cells. Following TSV infection, the cells were exposed for $24 \mathrm{~h}$ to various chlorobenzoxime concentrations. Images were captured at x250 magnification

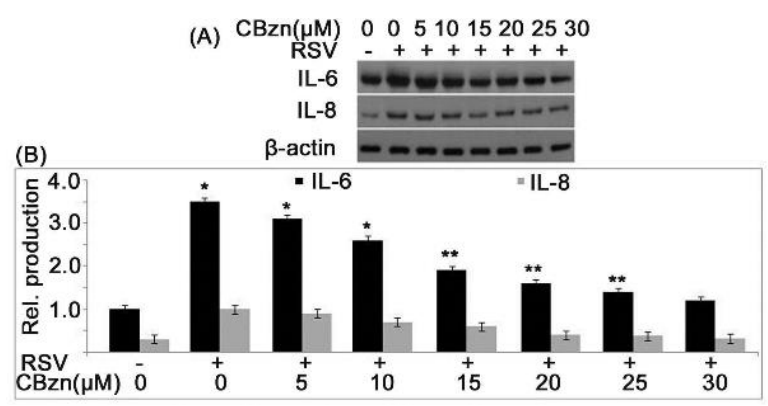

Figure 3: Inhibitory effect of chlorobenzoxime on RSV-mediated cytokine up-regulation. Interleukin-6 and interleukin-8 expressionsin BEAS-2B cells infected with RSV and exposed to chlorobenzoxime were determined with $(A)$ western blotting, and $(B)$ RT-PCR. Data are presented as mean \pm SD $(n=3)$; ${ }^{*} p<0.05,{ }^{* *} p<0.02$, compared with negative control cells

\section{Chlorobenzoxime inhibited RSV-induced ROS generation in BEAS-2B cells}

Cells infected with RSV were examined for ROS production following chlorobenzoxime treatment at $24 \mathrm{~h}$. RSV infection significantly enhanced ROS generation in BEAS-2B cells, when compared to control cells (Figure 4). However, the RSV-induced ROS production in BEAS-2B cells was reduced concentration-dependently by chlorobenzoxime. The RSV-infected BEAS-2B cells were exposed to chlorobenzoxime at doses of $5,10,15,20,25$ and $30 \mu \mathrm{M}$ for 24 h postinfection, and then subjected to dichlorofluorescein diacetate staining. At a dose of $30 \mu \mathrm{M}$, chlorobenzoxime completely suppressed the RSV-mediated production of ROS in BEAS-2B cells.
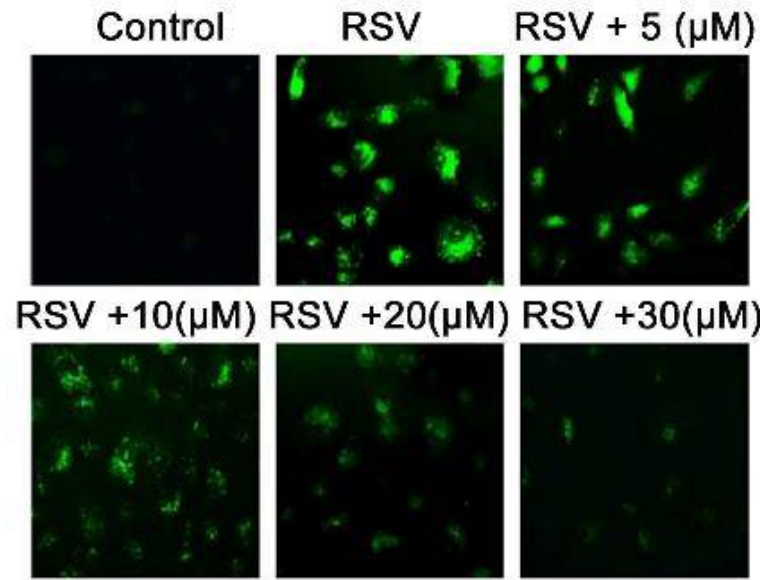

Figure 4: Effect of chlorobenzoximeon production of ROS by RSV. The RSV-infected and non-infected BEAS-2B cells were exposed for $24 \mathrm{~h}$ to chlorobenzoxime, and then stained for assessment of ROS generation. Data are expressed asmean \pm SD $(\mathrm{n}=3)$. ${ }^{*} p<0.05,{ }^{* *} p<0.01$, compared with negative control cells

\section{Chlorobenzoxime protected neonatal rats from RSV infection}

Infection of neonatal rats with RSV and treatment with chlorobenzoxime or saline was followed by assessment of cytokine and IFN-Y expressions in BALF (Figure $5 \mathrm{~A}$ ) and lung tissues (Figure 5 B). In RSV-infected neonatal rats, the expression of cytokines was increased significantly, whereas IFN-y expression was decreased in BALF. The RSV-induced increases in expressions of the inflammatory cytokines i.e. interleukin-4, interleukin-13 and TNF-awere suppressed in BALF by chlorobenzoxime treatment in the neonatal rats.

The suppression of RSV-induced expressions of inflammatory cytokines was maximum in neonatal rats treated with chlorobenzoxime at a dose of $10 \mathrm{mg} / \mathrm{kg}$. The RSV-mediated reduction in IFN- $\gamma$ was prevented maximum at $10 \mathrm{mg} / \mathrm{kg}$ dose of chlorobenzoxime in the neonatal rats. In the lung tissues of the neonatal rats, the enhanced expressions of interleukin-4, interleukin-5, interleukin-13 and TNF- $\alpha$ were suppressed by treatment with chlorobenzoxime 
(Figure $5 \mathrm{~B}$ ). The RSV-mediated suppression of IFN-y in the lung tissues of neonatal rats was also prevented by treatment with chlorobenzoxime.

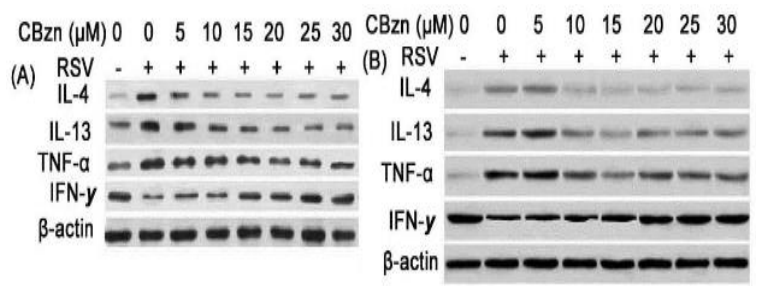

Figure 5: Effect of chlorobenzoxime on cytokine production in neonatal rats. Neonatal rats infected with RSV and treated with chlorobenzoxime were sacrificed, and BALF and lung tissues were usedfor determination of cytokine levels. The levels of interleukin-4, interleukin-5, interleukin-13, TNF- $\alpha$ and IFN-Y (A) BALF, and (B) lung tissues were determined using western blotting assay

\section{Chlorobenzoxime treatment of RSV-infected neonatal rats enhanced the proportion of IFN-y-producing cells}

Flow cytometric analysis of IFN-y stained BALF on day 7 of RSV infection showed that treatment of neonatal rats with chlorobenzoxime enhanced the proportion of IFN-y-producing cells (CD4+ T) (Figure 6). The proportion of IFN-y-producing cells in RSV-infected neonatal rat BALF was increased to $22.19 \%$, relative to $10.46 \%$ in the untreated group. Chlorobenzoxime also increased the percentage of CD11b+ in RSVinfected neonatal rats, when compared to untreated group. Treatment of the RSV-infected neonatal rats with chlorobenzoxime caused 4fold enhancement in the population of CD11C+ cells in BALF, when compared to the untreated group.

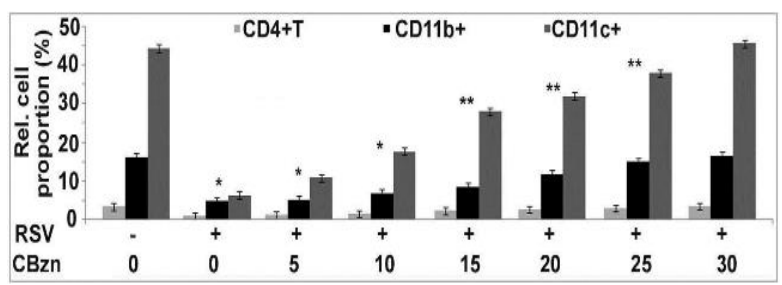

Figure 6: Effect of chlorobenzoxime on IFN-Yproducing cells in neonatal rat BALF. The BALF of neonatal rats infected with RSV and uninfected rats administered chlorobenzoxime at doses of 5 and 10 $\mathrm{mg} / \mathrm{kg}$ were analysed for CD4+ T, CD11b+ and CD11c+ cells

\section{DISCUSSION}

In the present study, chlorobenzoxime exhibited inhibitory effect on RSV replication in epithelial alveolar cells, prevented cell death, and suppressed the expressions of cytokine in vitro. It also inhibited cytokine generation, enhanced antiviral IFN- $\gamma$ production, and increased the population of IFN- $\mathrm{r}$-producing cells in neonatal rats infected with RSV.

It has been shown that RSV infection is one of the most common causes of respiratory disorders associated with asthma and lung diseases in the early and latter stages of life [20]. Infection by RSV causes cell damage through production of inflammatory cytokines, leading to oxidative damage [5]. The TSVinduced disturbance in balance between ROS generation and levels of anti-oxidants results in oxidative damage in cells [5].High levels of proinflammatory cytokines are responsible for RSVmediated respiratory tract disease [21]. The upregulated expressions of pro-inflammatory cytokines by RSV infection resulted in activation of nuclear factor-KB [22]. In the present study, chlorobenzoxime treatment of the RSV-infected lung alveolar cells resulted in significant inhibition RSV replication, when compared to non-infected cells.

Treatment of lung alveolar cells with chlorobenzoxime inhibited RSV-mediated cell death and morphological damage. Chlorobenzoxime exposure to the lung alveolar cells markedly prevented RSV-mediated reduction in viability, relative to untreated cells. The RSV infection inhibited lung alveolar cell viability partly through increase in ROS production. However, treatment of the lung alveolar cells with chlorobenzoxime inhibited the RSV-induced increase in ROS production. These findings from in vitro study suggest that chlorobenzoxime prevents RSV-mediated reduction in lung alveolar cell viability partly through suppression of cytokine production, and partly through inhibition of ROS generation.

The differentiation of $T$ cells is chiefly determined by dendritic cells [17]. In the present study, the effect of chlorobenzoxime on dendritic cell population in the RSV-infected neonatal rats was investigated. The results showed that treatment of RSV-infected neonatal rats with chlorobenzoxime significantly enhanced the proportion of IFN- $\gamma$-producing cells in BALF, when compared to untreated cells. Examination of the BALF showed that chlorobenzoxime treatment increased the population of CD4 T lymphocytes in BALF, relative to BALF CD4 T lymphocytes from the untreated group. The proportion of granulocytes i.e. CD11b+ and $\mathrm{CD} 11 \mathrm{C}+$ in the RSV-infected neonatal rat BALF was also increased on treatment with 
chlorobenzoxime, when compared to the untreated group.

Thus, chlorobenzoxime increased IFN- $\gamma$ production in neonatal rat BALF through upregulation of dendritic cell population. The increased populations of granulocytes and lymphocytes in the RSV-infected neonatal rat BALF suggest that chlorobenzoxime exerts its effects through modulation of cell phenotypes that produce inflammatory cytokines.

\section{CONCLUSION}

The present study demonstrates that chlorobenzoxime prevents RSV-induced oxidative damage via increase in antiinflammatory cytokines and inhibition of viral growth. Thus, chlorobenzoxime may be of immense benefit in the prevention of RSV infection.

\section{DECLARATIONS}

\section{Conflict of interest}

No conflict of interest is associated with this work.

\section{Contribution of authors}

We declare that this work was done by the authors named in this article and all liabilities pertaining to claims relating to the content of this article will be borne by the authors. Yonghai Zhang designed the study and wrote the paper. Junzhao $\mathrm{Li}$ and Hongmei Qiao performed the experimental work, Yingji Jin carried out the literature study and compiled the data. Jianmin Wang and Binghua Yao performed literature survey, analyzed the data and compiled the data. The research article was thoroughly read by all the authors before commination for the consideration of publication.

\section{Open Access}

This is an Open Access article that uses a funding model which does not charge readers or their institutions for access and distributed under the terms of the Creative Commons Attribution License (http://creativecommons.org/licenses/by/ 4.0) and the Budapest Open Access Initiative (http://www.budapestopenaccessinitiative.org/rea d), which permit unrestricted use, distribution, and reproduction in any medium, provided the original work is properly credited.

\section{REFERENCES}

1. Mäkelä MJ, Puhakka T, Ruuskanen $O$, Leinonen $M$, Saikku $P$, Kimpimäki M, Blomqvist S, Hyypiä T, Arstila $P$. Viruses and bacteria in the etiology of the common cold. J. Clin. Microbiol.1998;36: 539542.

2. Eccles MP, Grimshaw JM, Johnston $M$, Steen $N$, Pitts $N B$, Thomas R, Glidewell E, Maclennan G, Bonetti $D$, Walker A. Applying psycho-logical theories to evidence based clinical practice: identifying factors predictive of managing upper respiratory tract infections without antibiotics. Implement Sci.2007; 2: 26.

3. Murphy BR, Prince GA, Collins PL, Van Wyke Coelingh K, Olmsted RA, Spriggs MK, Parrott RH, Kim HW, Brandt $C D$, Chanock RM. Current approaches to the development of vaccines effective against parainfluenza and respiratory syncytial viruses. Virus Res. 1988; 11: 115.

4. Kim HW, Canchola JG, Brandt CD, Pyles G, Chanock RM, Jensen K, Parrott RH. Respiratory syncytial virus disease in infants despite prior administration of antigenic inactivated vaccine. Am. J. Epidemiol.1969; 89: 422-434.

5. Collins PL, Graham BS. Viral and host factors in human respiratory syncytial virus pathogenesis. J. Virol. 2008; 82: 2040-2055.

6. Chin J, Magoffin RL, Shearer LA, Schieble JH, Lennette $E H$. Field evaluation of a respiratory syncytial virus vaccine and a trivalent parainfluenza virus vaccine in a pediatric population. Am. J. Epidemiol.1969; 89: 449463.

7. Fulginiti VA, Eller JJ, Sieber OF, Joyner JW, Minamitani M, Meiklejohn G. Respiratory virus immunization. I. A field trial of two inactivated respiratory virus vaccines; an aqueous trivalent parainfluenza virus vaccine and an alum-precipitated respiratory syncytial virus vaccine. Am. J. Epidemiol. 1969; 89: 435-448.

8. Garofalo RP, Kolli D, Casola A. Respiratory syncytial virus infection: mechanisms of redox control and novel therapeutic opportunities. Antioxid. Redox Signal 2013; 18: 186-217.

9. Becker S, Soukup J, Yankaskas JR. Respiratory syncytial virus infection of human primary nasal and bronchial epithelial cell cultures and bronchoalveolar macrophages. Am. J. Respir. Cell Mol. Biol. 1992; 6: 369-374.

10. Rudd BD, Burstein E, Duckett CS, Li X, Lukacs NW. Differential role for TLR3 in respiratory syncytial virusinduced chemokine expression. J. Virol.2005; 79: 33503357.

11. Hong CE, Lyu SY. Anti-inflammatory and anti-oxidative effects of Korean red ginseng extract in human keratinocytes. Immune Netw.2011; 11: 42-49.

12. Culley FJ, Pennycook AM, Tregoning JS, Hussell T, Openshaw $P J$. Differential chemokine expression following respiratory virus infection reflects Th1- or Th2biased immunopathology. J. Virol., 2006; 80: 45214527.

Trop J Pharm Res, February 2020; 19(2): 252 
13. Z Jiang, M Kunimoto, JA Patel. Autocrine regulation and experimental modulation of interleukin- 6 expression by human pulmonary epithelial cells infected with respiratory syncytial virus. J. Virol.1998; 72: 2496-2499.

14. Hammad H, Lambrecht BN. Dendritic cells and epithelial cells: linking innate and adaptive immunity in asthma. Nat. Rev. Immunol. 2008; 8: 193-204.

15. Kwok HH, NgWY, Yang MS, Mak NK, Wong RN, Yue PY. The ginsenoside protopanaxatriol protects endothelial cells from hydrogen peroxide-induced cell injury and cell death by modulating intracellular redox status. Free Radic. Biol. Med.2010; 48: 437-445.

16. Pulendran B. Modulating vaccine responses with dendritic cells and Toll-like receptors. Immunol. Rev. 2004; 199: 227-250.

17. Quan FS, Kim Y, Lee S, Yi H, Kang SM, J Bozja, ML Moore, RW Compans. Virus like particle vaccine induces protection against respiratory syncytial virus infection in mice. J. Infect. Dis. 2011; 204: 987-995.
18. Song JM, Hossain J, Yoo DG, Lipatov AS, Davis CT, Quan FS, Chen LM, Hogan RJ, Donis RO, Compans $R W$, Kang SM. Protective immunity against H5N1 influenza virus by a single dose vaccination with viruslike particles. Virology 2010; 405: 165-175.

19. Song JM, Van Rooijen N, Bozja J, Compans RW, Kang $S M$. Vaccination inducing broad and improved cross protection against multiple subtypes of influenza $A$ virus. Proc. Natl. Acad. Sci. USA, 2011; 108: 757-761.

20. Panuska JR, Midulla F, Cirino NM, Villani A, Gilbert IA, McFadden ER, Jr, Huang YT. Virus-induced alterations in macrophage production of tumor necrosis factor and prostaglandin E2. Am. J. Physiol. 1990;259: L396 L402.

21. Zeng R, Li C, Li N, Wei L, Cui Y. The role of cytokines and chemokines in severe respiratory syncytial virus infection and subsequent asthma. Cytokine 2011; 53: 17.

22. Jie YH, Cammisuli S, Baggiolini M. Immunomodulatory effects of Panax Ginseng C.A. Meyer in the mouse. Agents Actions 1984; 15: 386-391. 